\title{
Effect of public hospital managers' risk and gain perception on their attitude towards physician dual practice: a cross-national study in 31 provinces of China
}

Yuanyuan Yu ${ }^{1,2}$, William C. S. Cho ${ }^{3}$, Qiaoman Liư ${ }^{4}$ Xiaojing Fan ${ }^{5}$, Xiaolin Chen ${ }^{6}$, Xihe Yu ${ }^{1}$, Yijun Lv ${ }^{6}$ and Xiumin Zhang ${ }^{1 *}$

\begin{abstract}
Background: This study aims to explore the effect of public hospital managers' risk and gain perception on their attitude towards physician dual practice (PDP).

Methods: A cross-sectional study enrolling 1513 managers from public hospitals in the East, Middle and West of China was conducted. Generalized linear mixed models (GLMM) were used to identify the determinants of managers' support for PDP.

Results: The rate of managers' support for allowing PDP or implementing PDP with restriction, was 94.3\% (95\% Cl: $0.93,0.95)$. The mean score of managers' risk perception was $67.7 \pm 14.46$, and the mean score of managers' gain perception was $24.0 \pm 5.56$. After controlling for individual and institutional characteristics, the GLMM presented the score for risk perception increased 1 score and the rate of managers' support for PDP decreased by 5\% (OR $=0.95$, $95 \% \mathrm{Cl}: 0.93,0.97)$; while the score for gain perception increased 1 score and the rate of managers' support increased by $18 \%(\mathrm{OR}=1.18,95 \% \mathrm{Cl}: 1.12,1.24)$.
\end{abstract}

Conclusions: Our data demonstrate that the majority of Chinese public hospital managers are in favor of allowing or implementing PDP with restrictions. Although gain perception is comparatively weaker than risk perception, a stronger influence in determining public hospital managers' support for PDP is demonstrated.

Keywords: Physician dual practice, Determinants, Public hospital, China

\section{Background}

In contrast to population health care needs, health care service provision is in shortage, which is quite common in both developed and developing countries [1, 2]. Hence, physician dual practice (PDP), a phenomenon that a physician can perform clinical practice in both the public and private sectors [3-5], is believed to provide

\footnotetext{
* Correspondence: xiu_min@jlu.edu.cn

'School of public health, Jilin University, No.1163 Xinmin Street, Chaoyang District, Changchun 130000, Jilin Province, China

Full list of author information is available at the end of the article
}

greater access to health care services for more patients [6-8]. According to common opinions from 15 of the world's top medical experts and health policy makers, as well as from evaluations from the World Health Organization (WHO), PDP ranks the second among global health care human resources research concerns [9]. Through PDP, physicians can increase their income and professional satisfaction [10]. PDP may also reduce the financial burden on governments to retain high quality medical service in the public sector $[7,11]$. However, debates on the disadvantages of PDP never cease, and

(C) The Author(s). 2020 Open Access This article is licensed under a Creative Commons Attribution 4.0 International License, which permits use, sharing, adaptation, distribution and reproduction in any medium or format, as long as you give appropriate credit to the original author(s) and the source, provide a link to the Creative Commons licence, and indicate if changes were made. The images or other third party material in this article are included in the article's Creative Commons licence, unless indicated otherwise in a credit line to the material. If material is not included in the article's Creative Commons licence and your intended use is not permitted by statutory regulation or exceeds the permitted use, you will need to obtain permission directly from the copyright holder. To view a copy of this licence, visit http://creativecommons.org/licenses/by/4.0/ The Creative Commons Public Domain Dedication waiver (http://creativecommons.org/publicdomain/zero/1.0/) applies to the data made available in this article, unless otherwise stated in a credit line to the data. 
negative effects of physicians engaging in public sectors and private sectors by far exceed the positive [12, 13]. Considering limits of the resources, physicians engaging in PDP may shirk their public sector duties due to competition for time, and reduce the quantity or quality of their services in public sector due to conflict of interest [14]. Furthermore, PDP also gives opportunity to hidden outflow of public sector resources, especially highly skilled physicians, rich and low complicated patients [15]. Therefore, further exploration and investigation are needed as effect might change in different contexts [5].

In 2009, China initiated new health-care reform with aims of achieving accessible and affordable health care service with full coverage for the entire population [16]. As a result, "Public Hospital Reform" and "Encouraging Private Hospital" became more important than before. Acting as a bridge between the public and private sectors, PDP draws great attention from both the government and general public for the equity, efficiency and quality of health care provision [17]. The policies and regulations on PDP underwent favorable changes in the last decade (Fig. 1). However, PDP did not enter a booming stage as expected, and substantial there are hot debates on how PDP impacts public hospitals' performance has ensued [10]. According to a survey of 35,500 Chinese physicians, $50 \%$ of practitioners did not participate in the PDP due to the reluctant attitudes public hospitals towards PDP [18]. This finding is supported by a previous study, which identified that $71.6 \%$ of the Chinese physicians reported that the resistance to PDP originated from the administration of the public hospitals [19]. In China, public hospitals take most of the responsibilities for their physicians professional development, and invest a lot during physicians career life. In turn, physicians make public hospitals trustworthy and the priority for patients. However, the intrinsic characteristic of PDP is mobility, which threatens the interdependence between public hospitals and their physicians. Moreover, PDP greatly challenges the continuity and constancy of public hospitals' personnel management, performance appraisal, compensation system, social security payment, medical risk insurance etc., thus affects the supervision capacities of public hospitals and increases their administration costs [20]. Hence, it is important to investigate the public hospital managers' attitude towards PDP, as well as the determinants.

This study which analyzed survey data collected in the East, Middle and West of China, aims to investigate the determinants influencing public hospital managers' support for PDP by using risk and gain perspectives that are based on valence-instrumentality-expectancy (VIE) theory. VIE theory is widely applied in psychological and behavioral studies to explain decision process and job performance, with a three-way interaction between (a) the importance attached to certain outcomes (Valence), (b) the extent to which performance is believed to result in these outcomes (Instrumentality), and (c) the extent to which extended effort is believed to result in effective performance (Expectancy) [21, 22]. In other words, an individual's decision is given by the sum of positive and negative values (Valences), individual attaches to outcomes and individual performance-outcome probability (Instrumentality) multiplied by individual effort-performance probability (Expectancy). VIE theory argues that role perceptions of positive and negative values are important determinants of job performance. This study hypothesizes that a managers' risk perception (a negative value), as well as their gain perception (positive values), could influence their decision in supporting PDP in a public hospital setting.

\section{Methods}

\section{Data source}

From January to October in 2019, we conducted a hospital-based survey with coverage of 31 provinces in the East, Middle and West of China. Managers of public hospitals who signed the informed consent were enrolled. This study used a convenience sample, at a series of meetings, conferences, and training sessions organized by the National Health Commission for public hospital managers, including: China Modern Hospital Management Seminars, National Tertiary Public Hospital Performance Evaluation Training Courses, Conference of Experience Exchange on China's Medical Reform, Conference of Experience Exchange on Hospital Discipline Development in China and so on. Presidents, vice-presidents in charge of clinical and medical affairs, and directors of medical affairs departments in China public hospitals were included in this study. In total, 1513 questionnaires were completed.

\section{Development of the instrument}

The risk and gain perception of managers was assessed based on a questionnaire (Supplementary material 1). The questionnaire developed as follows: 1) the two variables of risk and gain perception, derived from consumer purchase decision research, were modified according to the specific scenarios of PDP; 2) two rounds of expert consultation were conducted to make preliminary amendments to the initial scale. The expert group was composed of the managers from the Medical Administration Bureau and public hospitals, professors in the public health sectors, and doctors with a professional title. Items on the scale of risk and gain perception were discussed and measured carefully by experts before the questionnaire was finally approved; 3) a presurvey was conducted with a sample of 252 managers from public hospitals in Wenzhou city and Hangzhou city; 4) homogeneity test and the change of Cronbach's $\alpha$ coefficient were both applied for item selection. The 
Identify the concept "part-time work" for medical staffs

"Regulations on the management of part-time work for medical staffs"

In 1999

Allowing "Out for Consultation" with the approval and arrangement of employer

"Provisional Regulations on the Administration of Doctor's Consultation"

In 2005

Interim procedures for out-of-clinic consultation of physicians

In 2009

Implementing PDP in pilot provinces, practice sites no more than 3 in each province

"Notice on Physician Dual Practice"

In 2011

Expanding PDP to the whole nation, Employer's documentary approval is required

"Notice on Further Expanding the Pilot Scope of Physician Dual Practice"

Allowing PDP

"Decision on Key Issues for Deepening Comprehensive Reform"

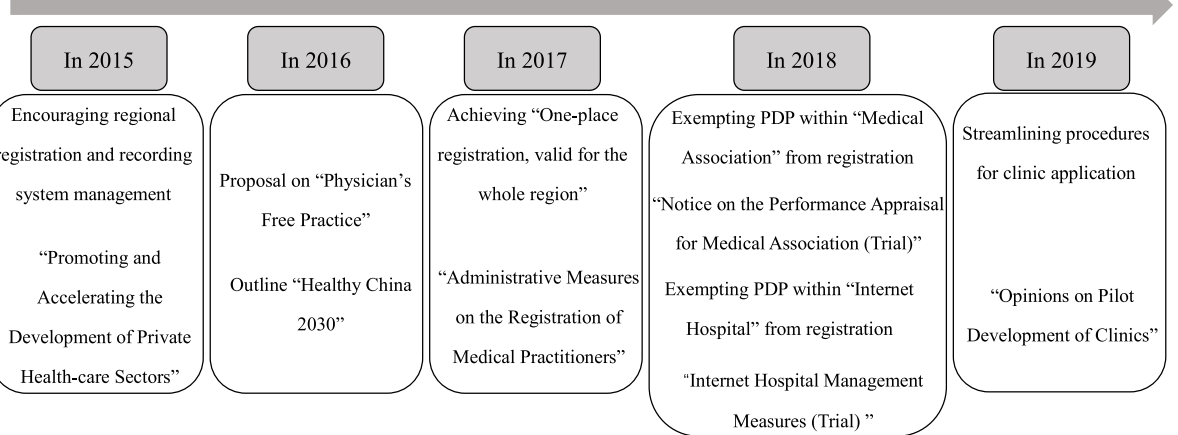

Fig. 1 The flow chart of physicians' dual practice policies

homogeneity test was used to calculate the correlation value (Corrected Item-Total Correlation, CITC) between each item's score and the total score of the scale as a criterion for deleting the item [23]. The CITC value of each item was higher than 0.5 , indicating that all the items of manager's risk and gain perception variables were highly homogeneous. Finally, Cronbach's $\alpha$ was used as a test for reliability [24], and confirmatory factor analysis was used as a validity test of the questionnaire [25].

\section{Study variables and sample size}

Managers were asked to evaluate their risk perception by answering 20 questions (Section B in Supplementary material 1) and their gain perception by answering 8 questions (Section C in Supplementary material 1) using a 5-step Likert scale. The answers were reported as: completely disagree (score 1), less agree (score 2), neutral (score 3), more agree (score 4) or completely agree (score 5). The outcome variable was managers' support for PDP (the first question in Section E). This category variable was divided between completely prohibited, and permitted (including allowing with restrictions and completely allowing). In this study, binary variables $(0=$ completely prohibited; $1=$ permitted) were used for the convenience of explaining a managers' support for PDP. According to the results of a previous study, the rate of support for managers for PDP was $44.5 \%$ [26]. Therefore, the sample size was calculated as 673 with a permissible error of $\delta=3 \%$, a type I error of $\alpha=0.05$ and an expected $20 \%$ non-response rate. 
We recruited a total of 1513 managers from the East, Middle and West of China in the public hospitals which met the requirement for statistical analysis.

\section{Quality control}

In order to ensure the results of the survey were accurate and reliable, we passed the results to experts with statistics expertise and experience of field research. Prior to the formal survey, research assistants were trained in accordance with a unified training plan and teaching materials. The training content included: the main purpose of the research, content, related terminology of this study and duration of this investigation; instructions for questionnaire filling and guidance for each item; explanations that may be necessary at the scene. This protocol ensured that all research assistants were familiar with the purpose and techniques required for survey, the meaning of the indicators and the content of the questionnaire before data collection. Each research assistant underwent a rigorous simulated training session before formal data collection. Regular monitoring of data collection was conducted throughout the data collection process.

\section{Statistical analysis}

In this study, all records have been checked for any missing data or outliers. The missing data in managers' support for PDP (outcome variable) and outliers in all selected variables were excluded prior to the data analysis. The scores of risk perception and gain perception were described with means and standard deviations of categorical variables including: sex, age, education, major, length of service, level of managers' position, institutional category, institutional level, institutional territory and location, which were ultimately summarized as percentages. The rates of managers' support for PDP were compared with Chi-squared test to identify the determinants. Generalized linear mixed models (GLMM) including fixed and random effects were used in this study to identify the determinants of managers' support for PDP when controlling for other confounding factors. The scores of risk and gain perception were specified as fixed effects and managers' work place as a random effect; managers' sex, age, education, major, length of service, level of managers' position, institutional category, institutional level, institutional territory and location were included as covariates (the detailed description was showed in Table 1). There are three models to explore the determinants: Three GLMMs were established from odds ratios (OR) together with 95\% confidence intervals (CIs) for each determinant regarding managers' support. Model 1 included the demographic determinants of managers' sex, age, and education. Model 2 included demographic determinants from model 1 plus managers' educational major, length of service, and level of managers' position. Model 3 included determinants from models 1 and 2 in addition to work environment determinants of managers' institutional category, institutional level, and institutional territory and location. All analyses were performed

Table 1 List of variables and description

\begin{tabular}{|c|c|}
\hline Variables & Description \\
\hline \multicolumn{2}{|l|}{ Demographic characteristics } \\
\hline Sex & 0: male; 1 :female \\
\hline Age (years) & $\begin{array}{l}\text { 1: aged less than } 40 \text { years old; 2: aged between } 41 \text { years old and } 50 \text { years old; } \\
\text { 3: more than } 51 \text { years old }\end{array}$ \\
\hline Education & 1: PhD; 2: Master; 3: Bachelor; 4: Others \\
\hline \multicolumn{2}{|l|}{ Work characteristics } \\
\hline Major & $\begin{array}{l}\text { 0: other majors (including administration, technology, economics, } \\
\text { management, et al); } 1 \text { :medicine }\end{array}$ \\
\hline Length of service (years) & $\begin{array}{l}\text { 1: works less than } 5 \text { years; 2: works between } 6 \text { years and } 10 \text { years; } 3 \text { : more } \\
\text { than } 11 \text { years }\end{array}$ \\
\hline Level of manager's position & $\begin{array}{l}\text { 0: manager's position is less than deputy division; 1: manager's position is more } \\
\text { than county level (including province level, city level, county level) }\end{array}$ \\
\hline \multicolumn{2}{|c|}{ Working environment characteristics } \\
\hline Institutional category & $\begin{array}{l}\text { 0: means special hospital, Chinese medicine hospital and others; 1:means } \\
\text { general hospital }\end{array}$ \\
\hline Institutional level & 0 : means primary level and second level; 1 :means tertiary level \\
\hline Institutional territory & 1: east of China; 2 :middle of China; 3 : west of China \\
\hline Location & $\begin{array}{l}0 \text { : means manager coming from provincial capital city; 1:means manager } \\
\text { coming from non-provincial capital city }\end{array}$ \\
\hline
\end{tabular}


with STATA statistical software version 12.0 (StataCorp LP, College station 77,845 , USA). A two-tailed $P$ value $<0.05$ was considered statistically significant.

\section{Results}

Reliability and validity of questionnaire

In this study, the Cronbach $\alpha$ coefficient of managers' risk and gain perception was more than 0.7 , which met the internal consistency requirements of the instruments. As a confirmatory factor analysis demonstrated, from the perspective of the standardized factor load of each measurement item corresponding to the risk and gain perception, both of confirmatory factor analysis were higher than 0.5 , with $P$ value less than 0.001 ; $C R$ was greater than 0.72; and AVE was greater than 0.46. Therefore, the risk and gain perception could achieve effective convergence aggregation, and the scale had good convergence validity.

\section{Demographics of managers in the public hospital}

The demographics of the sample of managers are listed in Table 2. There were 893 male managers and 623 female managers. About $57.44 \%$ of them majored in clinical medicine, including surgery, internal medicine, paediatrics, gynaecology, ophthalmology, otorhinolaryngology, dermatology, orthopaedics, psychiatry, traditional chinese medicine and general practice. Approximately $77 \%$ of the sample were under 50 years old and $51.51 \%$ had worked in the current positions for more than 6 years. Most of the managers' positions were lower than county level (77.86\%) with education levels higher than a baccalaureate (95.77\%). 37.91\% of the sample were from the East of China, 29.69\% from the Middle of China, and $32.40 \%$ from the West of China. $94.74 \%$ of the sample worked in a public tertiary hospital, the primary source of PDP.

\section{Distribution of different perception of managers' support for PDP}

The mean score of managers' risk perception was $67.7 \pm$ 14.46 and reflected differences in terms of managers' sex, age, major, length of service, institutions category, institutional level and location of managers' hospital $(P<0.05)$. The mean score of risk perception for female managers was $68.8 \pm 13.49$, which was higher than for male managers $(66.9 \pm 15.05)$. With increasing age, the mean score of risk perception increased, with managers aged 51 years old having the highest score for risk perception $(68.7 \pm 15.30)$. Managers from majors other than clinical medicine $(69.6 \pm 13.46)$ and those with longer lengths of service $(6-10$ years: $67.4 \pm 15.18$; $\geq 11$ years: $67.8 \pm 15.50)$ held higher risk perception.

In contrast, the mean score of managers' gain perception of $24.0 \pm 5.56$ was correlated with managers' age, length of
Table 2 Basic characteristics of managers $(n=1513)$

\begin{tabular}{lll}
\hline Variables & $\mathrm{n}$ & $\%$ \\
\hline $\begin{array}{l}\text { Demographic characteristics } \\
\text { Sex }\end{array}$ & & \\
$\quad$ Male & 893 & 59.02 \\
$\quad$ Female & 620 & 40.98 \\
Age (years) & & \\
$\quad \leq 40$ & 452 & 29.87 \\
$41-50$ & 713 & 47.13 \\
$\quad \geq 51$ & 348 & 23.00 \\
Education & & \\
PhD & 72 & 4.76 \\
Master & 398 & 26.31 \\
Bachelor & 979 & 64.71 \\
Others & 64 & 4.23
\end{tabular}

\section{Work characteristics}

Major

$\begin{array}{lll}\begin{array}{ll}\text { Others } \\ \text { Medicine }\end{array} & 644 & 42.56 \\ \text { Length of service (years) } & 869 & 57.44 \\ \quad \leq & & \\ 6-10 & 628 & 48.49 \\ \geq 11 & 338 & 26.10 \\ \text { Level of manager's position } & 329 & 25.41 \\ \quad \text { < Deputy division } & & \\ \quad \geq \text { Country level } & 1178 & 77.86 \\ \end{array}$

Working environment characteristics

Institutional category

Others

$537 \quad 34.49$

General hospital

976

64.51

Institutional level

$<$ tertiary level

72

5.26

tertiary level

1298

94.74

Institutional territory

East

572

37.91

Middle

448

29.69

West

489

32.41

Location

Provincial capital city

Non-provincial capital city

988

65.30

service and institutional level $(P<0.05)$. The score of managers' gain perception was highest in managers aged less than 40 years old $(24.5 \pm 4.96)$. Managers with length of service of 6-10 years held higher gain perception scores than those with less than 5 years or more than 11 years of 
service. It is noteworthy that managers in tertiary hospitals had a higher risk perception $(68.6 \pm 14.24, P<0.001)$, but lower gain perception $(23.8 \pm 5.51, P=0.003)$ than managers from public hospitals. (Table 3 ).
Distribution of demographics of managers among the rate of support for PDP

The rate of managers' support for allowing PDP and implementing PDP with restrictions was 94.3\% (95\% CI: 0.93,

Table 3 Descriptive of total score of different perception of managers' support for physician dual practice

\begin{tabular}{|c|c|c|c|c|c|c|}
\hline \multirow[t]{2}{*}{ Variables } & \multicolumn{3}{|c|}{ Risk perception } & \multicolumn{3}{|c|}{ Gain perception } \\
\hline & Mean & Std.Dev & $P$ & Mean & Std.Dev & $P$ \\
\hline \multicolumn{7}{|l|}{ Demographic characteristics } \\
\hline Sex & & & 0.006 & & & 0.240 \\
\hline Male & 66.9 & 15.05 & & 24.1 & 5.66 & \\
\hline Female & 68.8 & 13.49 & & 23.9 & 5.42 & \\
\hline Age (years) & & & 0.004 & & & $<0.001$ \\
\hline$\leq 40$ & 33.8 & 13.13 & & 24.5 & 4.96 & \\
\hline $41-50$ & 67.8 & 14.83 & & 23.9 & 5.68 & \\
\hline$\geq 51$ & 68.7 & 15.30 & & 23.6 & 6.03 & \\
\hline Education & & & 0.087 & & & 0.315 \\
\hline $\mathrm{PhD}$ & 66.2 & 15.40 & & 24.7 & 5.75 & \\
\hline Master & 66.7 & 13.40 & & 24.0 & 5.27 & \\
\hline Bachelor & 68.0 & 14.80 & & 24.0 & 5.68 & \\
\hline Others & 71.3 & 13.50 & & 23.5 & 5.30 & \\
\hline \multicolumn{7}{|l|}{ Work characteristics } \\
\hline Major & & & $<0.001$ & & & 0.058 \\
\hline Others & 69.6 & 13.46 & & 23.7 & 5.32 & \\
\hline Medicine & 66.3 & 15.01 & & 24.2 & 5.73 & \\
\hline Length of service (years) & & & 0.032 & & & 0.029 \\
\hline$\leq 5$ & 67.3 & 13.85 & & 23.9 & 5.34 & \\
\hline $6-10$ & 67.4 & 15.18 & & 24.3 & 5.57 & \\
\hline$\geq 11$ & 67.8 & 15.50 & & 23.7 & 6.06 & \\
\hline Level of manager's position & & & 0.433 & & & 0.362 \\
\hline$\leq$ Deputy division & 67.7 & 14.36 & & 24.0 & 5.42 & \\
\hline$\geq$ County level & 67.8 & 14.80 & & 23.9 & 6.05 & \\
\hline \multicolumn{7}{|l|}{$\begin{array}{l}\text { Working environment } \\
\text { characteristics }\end{array}$} \\
\hline Institutional category & & & 0.007 & & & 0.157 \\
\hline Others & 68.9 & 13.53 & & 23.8 & 5.63 & \\
\hline General hospital & 67.0 & 14.90 & & 24.1 & 5.52 & \\
\hline Institutional level & & & $<0.001$ & & & 0.003 \\
\hline$<$ tertiary level & 59.4 & 15.66 & & 25.7 & 6.39 & \\
\hline tertiary level & 68.6 & 14.24 & & 23.8 & 5.51 & \\
\hline Institutional territory & & & 0.322 & & & 0.896 \\
\hline East & 66.3 & 14.10 & & 24.0 & 5.55 & \\
\hline Middle & 70.0 & 14.10 & & 23.5 & 5.48 & \\
\hline West & 67.3 & 14.9 & & 24.4 & 5.60 & \\
\hline Location & & & 0.004 & & & 0.076 \\
\hline Provincial capital city & 66.4 & 14.78 & & 24.3 & 5.69 & \\
\hline Non-provincial capital city & 68.4 & 14.24 & & 23.8 & 5.49 & \\
\hline
\end{tabular}


0.95). As listed in Table 4, the rate of managers' support for PDP demonstrated differences among age and institutional territory $(P<0.05)$, while managers' sex, education, major, length of service, level of managers' position, institutional category, level and location showed no significant difference on the rate of managers' support for PDP $(P>0.05)$. Managers aged 41-50 years old had the highest rate of support for PDP; $46.60 \%\left(\chi^{2}=11.27, P=0.004\right)$. Managers in

Table 4 Distribution of basic characteristic of managers among the rate of support for physician dual practice

\begin{tabular}{|c|c|c|c|c|c|c|c|}
\hline \multirow[t]{2}{*}{ Variables } & \multicolumn{2}{|l|}{ No } & \multicolumn{2}{|l|}{ Yes } & \multirow[t]{2}{*}{ Total } & \multirow[t]{2}{*}{$x^{2}$} & \multirow[t]{2}{*}{$P$} \\
\hline & $\mathrm{n}$ & $\%$ & $\mathrm{n}$ & $\%$ & & & \\
\hline \multicolumn{8}{|l|}{ Demographic characteristics } \\
\hline Sex & & & & & & 0.54 & 0.464 \\
\hline Male & 54 & 62.79 & 839 & 58.79 & 893 & & \\
\hline Female & 32 & 37.21 & 588 & 41.21 & 620 & & \\
\hline Age (years) & & & & & & 11.27 & 0.004 \\
\hline$\leq 40$ & 12 & 13.95 & 440 & 30.83 & 452 & & \\
\hline $41-50$ & 48 & 55.81 & 665 & 46.60 & 713 & & \\
\hline$\geq 51$ & 26 & 30.23 & 322 & 22.56 & 348 & & \\
\hline Education & & & & & & 1.26 & 0.738 \\
\hline $\mathrm{PhD}$ & 4 & 4.65 & 68 & 4.77 & 72 & & \\
\hline Master & 19 & 22.09 & 379 & 26.56 & 398 & & \\
\hline Bachelor & 58 & 67.44 & 921 & 64.51 & 979 & & \\
\hline Others & 5 & 5.81 & 59 & 4.13 & 64 & & \\
\hline \multicolumn{8}{|l|}{ Work characteristics } \\
\hline Major & & & & & & 1.58 & 0.208 \\
\hline Others & 31 & 36.05 & 613 & 42.96 & 644 & & \\
\hline Medicine & 55 & 63.95 & 814 & 57.04 & 869 & & \\
\hline Length of service (years) & & & & & & 1.42 & 0.492 \\
\hline$\leq 5$ & 31 & 44.29 & 597 & 48.73 & 628 & & \\
\hline $6-10$ & 17 & 24.29 & 321 & 26.20 & 338 & & \\
\hline$\geq 11$ & 22 & 31.43 & 307 & 25.06 & 329 & & \\
\hline Level of manager's position & & & & & & 0.626 & 0.429 \\
\hline$\leq$ Deputy division & 64 & 74.42 & 1114 & 78.07 & 1178 & & \\
\hline$\geq$ Country level & 22 & 25.58 & 313 & 21.93 & 335 & & \\
\hline \multicolumn{8}{|l|}{$\begin{array}{l}\text { Working environment } \\
\text { characteristics }\end{array}$} \\
\hline Institutional category & & & & & & 0.669 & 0.414 \\
\hline Others & 27 & 31.40 & 510 & 35.74 & 537 & & \\
\hline General hospital & 59 & 68.60 & 917 & 64.26 & 976 & & \\
\hline Institutional level & & & & & & 0.02 & 0.895 \\
\hline$<$ tertiary level & 4 & 4.94 & 68 & 5.28 & 72 & & \\
\hline tertiary level & 77 & 95.06 & 1221 & 94.72 & 1298 & & \\
\hline Institutional territory & & & & & & 6.26 & 0.044 \\
\hline East & 25 & 29.76 & 547 & 38.39 & 572 & & \\
\hline Middle & 35 & 41.67 & 413 & 28.98 & 448 & & \\
\hline West & 24 & 28.57 & 465 & 32.63 & 489 & & \\
\hline Location & & & & & & 0.18 & 0.668 \\
\hline Provincial capital city & 28 & 32.56 & 497 & 34.83 & 525 & & \\
\hline Non-provincial capital city & 58 & 67.44 & 930 & 65.17 & 988 & & \\
\hline
\end{tabular}


the East of China had the highest support for PDP(38.39\%), compared to those from the Middle of China (28.98\%) and the West of China $(32.63 \%)\left(\chi^{2}=6.26, P=0.044\right)$.

\section{Determinants of managers' support for PDP}

Table 5 shows the multivariate analysis of the determinants of managers' support for PDP by a generalized linear mixed model. According to the model 1, the total score of risk perception, gain perception, and age had a significant effect on the rate of managers' support for PDP. By controlling demographic characteristics from model 1 , when the risk perception increased 1 score, the rate of managers' support for PDP decreased 6\% (OR $=0.94,95 \% \mathrm{CI}$ : 0.92, 0.96). By controlling work characteristics and working environment characteristics, the results in model 2 and model 3 remained statistically significant $(P<0.001)$. Based on the results from model 1 , when the gain perception increased 1 score, the rate of managers' support for PDP increased by $17 \%$ (OR $=1.17,95 \%$ CI: $1.12,1.23)$. The results in model 3 remained statistically significant $(P<0.001)$ after controlling for work and working environment characteristics. Therefore, we can identify that risk perception is negatively correlated with managers' support for PDP, but gain perception is positively correlated with managers' support for PDP. The age of managers was significantly correlated with their support for PDP in model 1. The rate of managers' support decreased $52 \%$ for those aged $41-50$ years old (OR = 0.48, 95\% CI: 0.24, 0.96). By controlling demographic characteristics and work characteristics in model 2, the rate of managers' support decrease to $59 \%$ for those aged $41-50$ years old $(\mathrm{OR}=0.41,95 \% \mathrm{CI}: 0.17$, 0.97). However, when controlling for the demographic characteristics of work and working environment characteristics, there was no significant association between managers' age and their support for PDP.

\section{Discussion}

In this study, we found that the rate of managers' support for PDP in China is 94.3\%, including support with restrictions as well as complete support, which is consistent with the goals of policy introduced after 2009 [27]. According to the previous report, PDP had direct implications for access, equity, price and quality of the whole nation's health care service, and thus benefits the whole coverage of universal health [28]. This outcome could possibly explain why most managers in the public hospitals support PDP, as they have realized the advantages of PDP for improving health care service access to those under-served areas in China.

Judging by the results of our study, we are not surprise to find that the managers in the East of China (38.39\%) held the highest rate for favoring PDP, followed by those from the West of China (32.63\%). While managers from the Middle of China showed the lowest rate for favoring
PDP (28.98\%). These results may be explained by the extensive and distinguished Electronic Business (E-Business) and Information Technology (IT) industry development in the East, which connects all of China and brings easier access of PDP for both physicians and patients. According to China Internet Hospital Development Research Report 2020, the domestic health care market based on E-Business and IT has experienced an exponential growth. The scale of internet hospitals exceeded 49 billion RMB in 2018, 67.95 billion RMB in 2019, and was expected to exceed 100 billion RMB in 2020, with average daily visits of internet hospitals 2000-3000 [29].

According to our findings, risk perception and gain perception were significantly correlated with managers' support for PDP. That is, managers' support for PDP would increase when gain perception was being enhanced or risk perception was being controlled. Risk perception has been well identified as an intuitive and emotional structure closely related to human perception and behavior [30-32]. Obviously, it is important to reduce risk perception of managers. According to white book on medical practitioners in China 2018, involving 44,600 hospitals and 146, 200 physicians, the average weekly working hours in tertiary hospitals and secondary hospitals are $51.05 \mathrm{~h}$ and $51.13 \mathrm{~h}$ respectively, merely $19.2 \%$ physicians perceive themselves in good status during self-assessment, and psychological exhaustion of physicians is significantly greater than that of workers from other industries [33]. Constrained by limited time and energy, PDP may present as absenteeism, tardiness, inefficiency, and lack of motivation among public hospitals. So managers worry about physicians engaged in dual practice compromising service delivery. For Chinese policy-makers, promoting PDP through internet may greatly extend the outreach of PDP for physicians on one hand, and strength the capacities of monitoring and supervision for managers on the other. We could expect wide application of IT in health care industry, such as 5G, internet+, artificial intelligence and telemedicine, could pave the way for the popularity of PDP [34], and reduce the risk of physicians skimping of time and efforts in the public hospitals.

More importantly, this study also found that gain perception held more effects on the managers' support for PDP than risk perception, which may have some implications for the health-care authority in China. Previously, policy makers in China had long been neglecting the public hospital managers' gain perception towards PDP [35]. It could be largely explained by the negative attitudes of public hospital managers [36]. Many countries have prioritised gain perception [14]. For example, in the U.K., dual practitioners within the National Health Service (NHS) are required to pay $9 \%$ of their incomes as compensation to NHS. While in Germany, dual practitioners pay according to what is prescribed in their contracts with public hospitals. 
Table 5 Multivariate analysis of determinants of managers' support for physician dual practice by generalised linear mixed model $(n=1513)$

\begin{tabular}{|c|c|c|c|c|c|c|c|c|c|c|c|c|}
\hline \multirow[t]{3}{*}{ Variables } & \multicolumn{4}{|c|}{ Model 1} & \multicolumn{4}{|c|}{ Model 2} & \multicolumn{4}{|c|}{ Model 3} \\
\hline & \multirow[t]{2}{*}{$\overline{O R}$} & \multicolumn{2}{|l|}{$95 \% \mathrm{Cl}$} & \multirow[t]{2}{*}{$P$} & \multirow[t]{2}{*}{$\overline{\mathrm{OR}}$} & \multicolumn{2}{|l|}{$95 \% \mathrm{Cl}$} & \multirow[t]{2}{*}{$P$} & \multirow[t]{2}{*}{$\mathrm{OR}$} & \multicolumn{2}{|l|}{$95 \% \mathrm{Cl}$} & \multirow[t]{2}{*}{$P$} \\
\hline & & Lower & Upper & & & Lower & Upper & & & Lower & Upper & \\
\hline Risk perception & 0.94 & 0.92 & 0.96 & $<0.001$ & 0.94 & 0.92 & 0.96 & $<0.001$ & 0.95 & 0.93 & 0.97 & $<0.001$ \\
\hline Gain perception & 1.17 & 1.12 & 1.23 & $<0.001$ & 1.18 & 1.12 & 1.23 & $<0.001$ & 1.18 & 1.12 & 1.24 & $<0.0$ \\
\hline
\end{tabular}

\section{Demographic characteristics}

Sex

\begin{tabular}{|c|c|c|c|c|c|c|c|c|c|c|c|c|}
\hline Male & 1.00 & & & & 1.00 & & & & 1.00 & & & \\
\hline Female & 1.40 & 0.85 & 2.32 & 0.187 & 1.59 & 0.88 & 2.86 & 0.122 & 1.69 & 0.91 & 3.15 & 0.098 \\
\hline \multicolumn{13}{|l|}{ Age (years) } \\
\hline$\leq 40$ & 1.00 & & & & 1.00 & & & & 1.00 & & & \\
\hline $41-50$ & 0.48 & 0.24 & 0.96 & 0.038 & 0.41 & 0.17 & 0.97 & 0.042 & 0.44 & 0.18 & 1.09 & 0.076 \\
\hline$\geq 51$ & 0.47 & 0.22 & 1.01 & 0.052 & 0.42 & 0.16 & 1.11 & 0.081 & 0.42 & 0.15 & 1.17 & 0.098 \\
\hline
\end{tabular}

Education

\begin{tabular}{|c|c|c|c|c|c|c|c|c|c|c|c|c|}
\hline $\mathrm{PhD}$ & 1.00 & & & & 1.00 & & & & 1.00 & & & \\
\hline Master & 0.83 & 0.24 & 2.86 & 0.769 & 1.26 & 0.34 & 4.64 & 0.726 & 1.70 & 0.44 & 6.56 & 0.444 \\
\hline Bachelor & 0.83 & 0.26 & 2.65 & 0.757 & 1.17 & 0.35 & 3.95 & 0.801 & 1.33 & 0.37 & 4.78 & 0.659 \\
\hline Others & 0.78 & 0.17 & 3.53 & 0.748 & 1.39 & 0.23 & 8.33 & 0.721 & 1.65 & 0.25 & 10.83 & 0.602 \\
\hline
\end{tabular}

Work characteristics

$$
\begin{aligned}
& \text { Major } \\
& \text { Others } \\
& \text { Medicine } \\
& \text { Length of } \\
& \leq 5 \\
& 6-10 \\
& \geq 11
\end{aligned}
$$$$
\text { Medicine }
$$$$
\text { Length of service (years) }
$$

Level of manager's position

$\leq$ Deputy division

$\geq$ County level

\section{Working environment}

\section{characteristics}

Institutional category

Others

General hospital

Institutional level

$$
<\text { tertiary level }
$$

tertiary level

Institutional territory

$$
\begin{gathered}
\text { East } \\
\text { Middle } \\
\text { West } \\
\text { Location }
\end{gathered}
$$

Provincial capital city

Non-provincial capital city

$\begin{array}{llllllll}1.00 & & & & 1.00 & & & \\ 0.68 & 0.38 & 1.22 & 0.196 & 0.66 & 0.35 & 1.22 & 0.186 \\ & & & & & & & \\ 1.00 & & & & 1.00 & & & \\ 1.17 & 0.57 & 2.42 & 0.662 & 1.54 & 0.71 & 3.37 & 0.276 \\ 0.89 & 0.46 & 1.74 & 0.743 & 1.10 & 0.52 & 2.35 & 0.799 \\ & & & & & & & \\ 1.00 & & & & 1.00 & & & \\ 1.72 & 0.88 & 3.39 & 0.115 & 1.58 & 0.78 & 3.21 & 0.207\end{array}$

Model 1 included the demographical determinants of managers' sex, age, education. Model 2 included determinants in model 1 plus managers' major length of service, level of managers' position. Model 3 included determinants in model 1 and model 2 plus work environment determinants including managers' institutional category, institutional level, institutional territory and location 
On the other hand, many countries also developed effective measures to reduce risk perceptions of public hospitals, such as in France and Ireland, where private practice is encouraged within public hospitals during off-duty time for easier and better monitoring. Again in U.K., physicians of the NHS are required to work at least 4 days per week within public hospitals. While in Australia, public hospitals employ lawyers to lower the negative effects on normal running of the hospital once medical disputes concerning PDP occurred [14]. Therefore, it is effective ways for Chinese policymakers to establish reasonable benefit distribution mechanism, cost sharing mechanism, economic loss identification and compensation mechanism among the public and private sectors, so as to achieve the public hospital managers' sense of gain perception.

\section{Limitations}

Firstly, the determinants of managers' support for PDP in this cross-sectional study were constrained by the pre-set questions in the surveys. There may have been some potential unobserved confounding factors were not controlled in the generalised linear mixed model. Secondly, the investigation and survey were conducted for managers of public hospitals. Other PDP stakeholders, such as managers of private hospitals and health care authorities were excluded from the study. Thirdly, the relationship between physicians' support for PDP and that of hospital managers was unclear. More evidence based on quantitative studies and randomized controlled trials may throw light on the unknowns of the mutual interference of stakeholders' attitudes and behaviors towards PDP. This study used a convenience sampling method which may have resulted in a sample that is not representative of the larger population of public hospital managers in China. In order to yield more evidence based findings, randomized studies in this field are recommended.

\section{Conclusions}

This study found that the majority of public hospital managers in China were not against PDP, rather managers' support rate for PDP, including support with restrictions, was high. In other words, although public hospital managers in China disagreed with PDP according to various public reports, by implementing PDP with proper conditions left much flexibility and feasibility for the government to achieve optimizing the productivity and capacity of medical resources.

\section{Supplementary information}

Supplementary information accompanies this paper at https://doi.org/10. 1186/s12889-020-09207-1.

Additional file 1.

\section{Abbreviations}

PDP: Physician Dual Practice; VIE: Valence-Instrumentality-Expectancy; GLMM: Generalized Linear Mixed Model; WHO: World Health Organisation; Cl: Confidence Index; OR: Odds Risk; NHS: National Health Service;

IT: Information Technology

\section{Acknowledgements}

We express our appreciation to all participants in this study for their participation and co-operation.

\section{Authors' contributions}

$Y Y, X C, X Z$ were responsible for the field work, including data collection and management. YY, WCC, XZ and QL provided suggestions for data analysis. $X F, Y Y, Q L$ and $S X$ were responsible for the sorting of data. $Y Y, X F$ and $X C$ performed the statistical analysis. The manuscript was prepared by $Y Y, X F$, $X C, X Y, Y L, W C C$ and XZ. All authors critically reviewed and approved the final manuscript.

\section{Funding}

This study was funded by the National Social Science Fund of China (No. 18BGL247). The funding body had no role in the design of the study and collection, analysis, and interpretation of data and in writing the manuscript.

\section{Availability of data and materials}

The dataset and materials used in this study are available from the corresponding author on reasonable request.

\section{Ethics approval and consent to participate}

This study was approved by the Ethics Committee in Clinical Research of First Affiliated Hospital of Wenzhou Medical University (No 2020-011). Written informed consent and data permission were received from participants together with survey questionnaires.

Consent for publication

Not applicable.

\section{Competing interests}

The authors declare that they have no competing interests.

\section{Author details}

${ }^{1}$ School of public health, Jilin University, No.1163 Xinmin Street, Chaoyang District, Changchun 130000, Jilin Province, China. ${ }^{2}$ First Affiliated Hospital of Wenzhou Medical University, Nanbaixiang, Ouhai District, Wenzhou 325000, Zhejiang Province, China. ${ }^{3}$ Department of Clinical Oncology, Queen Elizabeth Hospital, Hong Kong, SAR, China. ${ }^{4}$ Jiangsu Vocational Institute of Commerce, No.180 Longmian Street, Jiangning District, Nanjing 210012, China. ${ }^{5}$ School of Public Policy and Administration, Xi'an Jiaotong University, No. 28 Xianning West Road, Xi'an 710049, Shaanxi, China. ${ }^{6}$ Wenzhou Medical University, Nanbaixiang, Ouhai District, Wenzhou 325000, Zhejiang Province, China.

Received: 16 March 2020 Accepted: 5 July 2020

Published online: 13 July 2020

\section{References}

1. Elliott B. Labour markets in the NHS: an agenda for research. Health Econ. 2003;12(10):797-801.

2. Salsberg E, Grover A. Physician workforce shortages: implications and issues for academic health centers and policymakers. Acad Med. 2006;81(9):782-7.

3. Johannessen KA, Hagen TP. Physicians' engagement in dual practices and the effects on labor supply in public hospitals: results from a register-based study. BMC Health Serv Res. 2014;14:299.

4. Socha KZ, Bech M. Physician dual practice: a review of literature. Health Policy. 2011;102(1):1-7.

5. Moghri J, Arab M, Rashidian A, Akbari Sari A. Physician dual practice: a descriptive mapping review of literature. Iran J Public Health. 2016; 45(3):278-88.

6. Gonzalez P. Should physicians' dual practice be limited? An incentive approach. Health Econ. 2004;13(6):505-24.

7. Garcia-Prado A, Gonzalez P. Whom do physicians work for? An analysis of dual practice in the health sector. J Health Polit Polic. 2011;36(2):265-94. 
8. Anthony CR, Moore M, Hilborne LH, Rooney A, Hickey S, Ryu Y, Botwinick L. Health sector reform in the Kurdistan region-Iraq: primary care management information system, physician dual practice finance reform, and quality of care training. Rand Health Q. 2018;8(2):1

9. McPake B, Russo G, Hipgrave D, Hort K, Campbell J. Implications of dual practice for universal health coverage. Bull World Health Organ. 2016;94(2):142-6.

10. Ferrinho P, Van Lerberghe W, Fronteira I, Hipolito F, Biscaia A. Dual practice in the health sector: review of the evidence. Hum Resour Health. 2004;2(1):14

11. Jan S, Bian $Y$, Jumpa M, Meng Q, Nyazema N, Prakongsai P, Mills A. Dual job holding by public sector health professionals in highly resource-constrained settings: problem or solution? Bull World Health Organ. 2005;83(10):771-6.

12. Gonzalez P, Macho-Stadler I. A theoretical approach to dual practice regulations in the health sector. J Health Econ. 2013;32(1):66-87.

13. Socha K, Bech M. The relationship between dual practice and physicians' work behaviour in the public hospitals: results from the Danish survey. Health Econ. 2011. https://doi.org/10.3760/cma.j.issn. 0366-6999.2011.22.036.

14. Kiwanuka SN, Kinengyere AA, Rutebemberwa E, Nalwadda C, Ssengooba F, Olico-Okui PGW. Dual practice regulatory mechanisms in the health sector: a systematic review of approaches and implementation. London: EPPICentre, Social Science Research Unit, Institute of Education, University of London.; 2010.

15. Moghri J, Rashidian A, Arab M, Sari AA. Implications of dual practice among health workers: a systematic review. Iran J Public Health. 2017;46(2):153-64.

16. Yip WCM, Hsiao WC, Chen W, Hu SL, Ma J, Maynard A. Early appraisal of China's huge and complex health-care reforms. Lancet. 2012; 379(9818):833-42.

17. Ariadna GP, Paula G. Policy and regulatory responses to dual practice in the health sector. Health Policy. 2007;84(2-3):0-152.

18. Physician dual practice resistance is still large, the pilot of the doctor's salary system is launched [https://finance.sina.com.cn/roll/2018-05-20/doc-ihaturft1 021028.shtml]

19. Zhu C, Sheng M, Song B. Policies related to physician multi-site practice: good but difficult to implement. Chin Gen Pract. 2019;22(1):85-90.

20. Ke $\mathrm{C}$, Jia H. Analysis of the current status of physician dual practice. Med and Soc. 2012;25(2):86-90.

21. Dillard JF. Valence-instrumentality-expectancy model validation using selected accounting groups. Acc Organ Soc. 1979;4(1):31-8.

22. Pritchard RD, Sanders MS. The influence of valence, instrumentality, and expectancy on effort and performance. J Appl Psychol. 1973;57(1):55-60.

23. Paul SR, Donner A. A compararison of tests of homogeneity of odds ratios in K 2×2 tables. Stat Med. 1989;8:1455-68.

24. Bland JM, Altman DG. Cronbach's alpha. BMJ. 1997;314(7080):572.

25. Capafons A, Espejo B, Mendoza ME. Confirmatory factor analysis of the Valencia Scale on attitudes and beliefs toward hypnosis, therapist version. Int J Clin Exp Hypn. 2008:56(3):281-94.

26. Lin K, Lin K, Wang Y, Xu X, Li W. Multiple-site physician practices in Guangdong Province:a survey of Stakeholders' perspectives. Chin Gen Pract. 2019;22(20):2514-8.

27. Hu S. Multiple-site physician practice in China:policy barriers and feasible path. Chin J Health Polic. 2014;7(1):5-7.

28. Sousa A, Scheffler RM, Nyoni J, Boerma T. A comprehensive health labour market framework for universal health coverage. Bull World Health Organ. 2013;91(11):892-4.

29. China Internet Hospital Development Research Report [http://zk.cnhealthcare.com/doc-show-39773.html ].

30. Yoshida M, Yanuaryska RD, Shantiningsih RR, Mudjosemedi M, Honda E. Comparison of radiation risk perception and knowledge of radiation between Indonesian and Japanese dental students. J Environ Radioact. 2019;204:104-10

31. Wilson RA-O, Zwickle AA-OX, Walpole H. Developing a broadly applicable measure of risk perception. Risk Anal. 2019;39(4):777-91.

32. Wiedemann PM, Freudenstein F, Bohmert C, Wiart J, Croft RJ. RF EMF Risk Perception Revisited: Is the Focus on Concern Sufficient for Risk Perception Studies? Int J Environ Res Public Health. 2017;14(6):E620. https://doi.org/10. 3390/ijerph14060620.

33. White paper on the practice status of Chinese physicians [http://www.cmda net/rdxw2/11526.jhtml].
34. Yu Y, Zhang X, Zheng Y, Chen X, Zhu X. The analysis of the positive and negative aspects of public hospital physician dual practice and suggestions on policy making. Med Soc. 2018;6(31):8-10.

35. Zhao R. Study on attitude difference between clinicians and hospital managers on multi-site physician practice in China. Med Soc. 2017; 30(11):60-3.

36. Wei S, Zhang X, Li Q, Dong H. Risk prevention of doctor multi-sited licensed under perspective of first registered hospital. Med Soc. 2017;30(10):38-40.

\section{Publisher's Note}

Springer Nature remains neutral with regard to jurisdictional claims in published maps and institutional affiliations.
Ready to submit your research? Choose BMC and benefit from:

- fast, convenient online submission

- thorough peer review by experienced researchers in your field

- rapid publication on acceptance

- support for research data, including large and complex data types

- gold Open Access which fosters wider collaboration and increased citations

- maximum visibility for your research: over $100 \mathrm{M}$ website views per year

At $\mathrm{BMC}$, research is always in progress.

Learn more biomedcentral.com/submissions 